Inside Academia 



\section{Inside Academia}

\section{$\sim$ \\ Professors, Politics, and Policies}

STEVEN M. CAHN

\section{Tid}

Rutgers University Press

New Brunswick, Camden, and Newark, New Jersey, and London 


\section{Library of Congress Cataloging-in-Publication Data}

Names: Cahn, Steven M., author.

Title: Inside academia : professors, politics, and policies / Steven M. Cahn. Description: New Brunswick, New Jersey : Rutgers University Press, [2018] | Includes bibliographical references and index.

Identifiers: LCCN 2018008402| ISBN 9781978801516 (cloth : alk. paper) | ISBN 978I978801509 (pbk. : alk. paper) | ISBN 9781978801523 (epub) | ISBN 9781978801547 (Web PDF)

Subjects: LCSH: Universities and colleges-United States-Administration. Education, Higher-Aims and objectives-United States. | Education, Higher-Curricula-United States. | College teachers-TenureUnited States. | College teaching-United States.

Classification: LCC LC234I .C 34 20I8 | DDC 378.I/oI-de23

$\mathrm{LC}$ record available at https://lccn.loc.gov/2018008402

\section{A British Cataloging-in-Publication record for this book is available} from the British Library.

\section{Copyright (C) 2019 by Steven M. Cahn}

All rights reserved

No part of this book may be reproduced or utilized in any form or by any means, electronic or mechanical, or by any information storage and retrieval system, without written permission from the publisher. Please contact Rutgers University Press, ro6 Somerset Street, New Brunswick, NJ o89or. The only exception to this prohibition is "fair use" as defined by U.S. copyright law.

( The paper used in this publication meets the requirements of the American National Standard for Information Sciences-Permanence of Paper for Printed Library Materials, ANSI Z39.48-I992.

www.rutgersuniversitypress.org

Manufactured in the United States of America 
To my wife,

Marilyn Ross, M.D. 
